\title{
Impact of Consumer Inertia on Purchase Intention under the Influence of Subjective Product Knowledge
}

\author{
${ }^{(1)}$ Khadija Saqib, ${ }^{(2)}$ Asif Mahmood, ${ }^{(3)}$ Maria Khan and ${ }^{(4)}$ Mariyam Hashmi \\ Institute of Business and Management, University of Engineering and Technology, \\ Lahore, Pakistan \\ Khadija.saqib25@gmail.com
}

\begin{abstract}
The research aimed to explore the relationship between consumer inertia and purchase intention through subjective product knowledge. Consumer inertia and purchase intention were analyzed as independent and dependent variables respectively whereas subjective product knowledge was observed as a moderator. This research was quantitative in nature. Data were collected from smartphone users through questionnaire. Convenient sampling technique was used to conduct the survey. Hierarchical regression analysis was applied to test the hypotheses. The results showed that there was a positive relationship between consumer inertia and purchase intention and through moderating role of subjective product knowledge it became stronger. Findings of this research suggested the subjective product knowledge as a good moderator of purchase intention. Additionally, subjective product knowledge was included as a moderator between the relationship of consumer inertia and purchase intention.
\end{abstract}

Keywords: Consumer inertia, purchase intention, subjective product knowledge, perceived value.

\section{Introduction.}

In marketing context, Isaac Newton's "law of inertia" has many dimensions. In the absence of other forces, consumers like to stay with their current products. In the presence of more charismatic substitutes, consumers want to affix to their products if they have high level of inertia [1]. For fresh, current products, market segmentation and promotional strategies the interest of marketing managers' lies in consumer purchase intention. For the sake of anticipation of current revenue, fresh arrivals and services along with helping marketing decisions that belong to product demand [2].Subjective Product Knowledge is significant sign to strengthen the intention in order to search the product categories. For this, information is assessed and collected for long. Consumers who have sure subjective product knowledge are lesser intended towards searching information about new product [3].

Consumer Inertia is defined that it's a usage pattern in which consumers unknowingly condescend the same product which is based on the past usage experience [1]. Inertia directs the consumers to make their buying decision without much deliberation. Inertia inclines the consumers to re-condescend a product [4]. Inertia forces the consumers to bypass business dealings with unknown providers and spends reasonable cost. It means that consumers with high inertia level unintentionally affix to their present goods and services provider and have their purchase intention in less intended way [5]. The following are the causes for consumer inertia 1) less usage time because consumers avoid to use new product or to have comparison of prices or services among products, 2) the consumers prefer to shop the product of which they have become used to. 3) They think over the minimum differences in features between the current product and substitutes [6]. 
The level in which the consumer is likely to make purchases in the time to come is termed as purchase intention. On the basis of the perceived value purchase intention is a complete judgment of the cost and benefits of a given marketing offering in a specific customer application. It shows the net gain that consumers have from their usage attitude[7]. On the basis of perceived value, purchase intention is rationally anticipated, for a product, by consumers. Perceived price, perceived usefulness and ease of use are the vital antecedents of perceived value. Many researchers have been supporting the importance of purchase intention in the context of product usage [8]. For the sake of attracting the consumers towards new market product, architecturing of purchase intention should be charismatic and dynamic [9].

As regards knowledge, two theoretically different constructs are outstanding; 1) Objective product knowledge 2) Subjective product knowledge. An authentic and precise set of information about a product which consumers have in their long term memory is termed as objective product knowledge whereas subjective product knowledge refers to the subjective perceptions of people what and how much they are well aware of a product [10]. One's subjective understanding and interpretation of one's knowing about a product is also part of the concept of subjective product knowledge. Previous researches prove subjective product knowledge as a positive emphasizer of purchase intention [11]. Moreover, more knowledge about product could enhance the chances to purchase a product [12].

\section{Materials and Methods}

This research was attempted to figure out the impact of consumer inertia on purchase intention under the moderating role of subjective product knowledge. Consumer inertia and purchase intention were used as independent variable and dependent variable respectively, whereas subjective product knowledge was taken as a moderator.

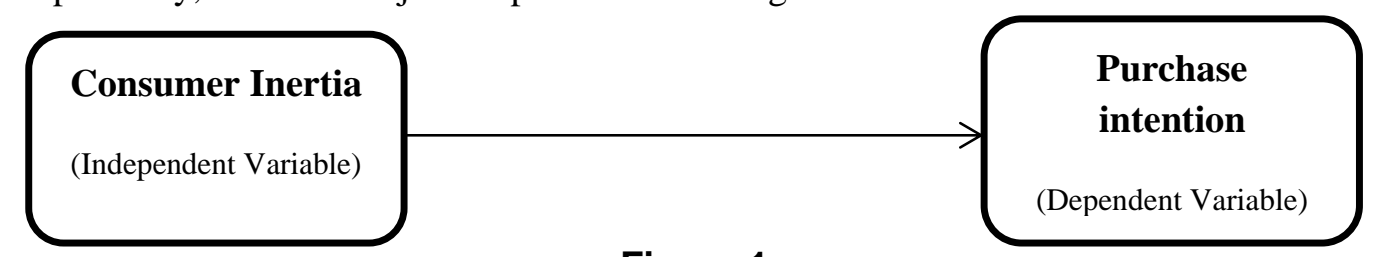

Figure 1.

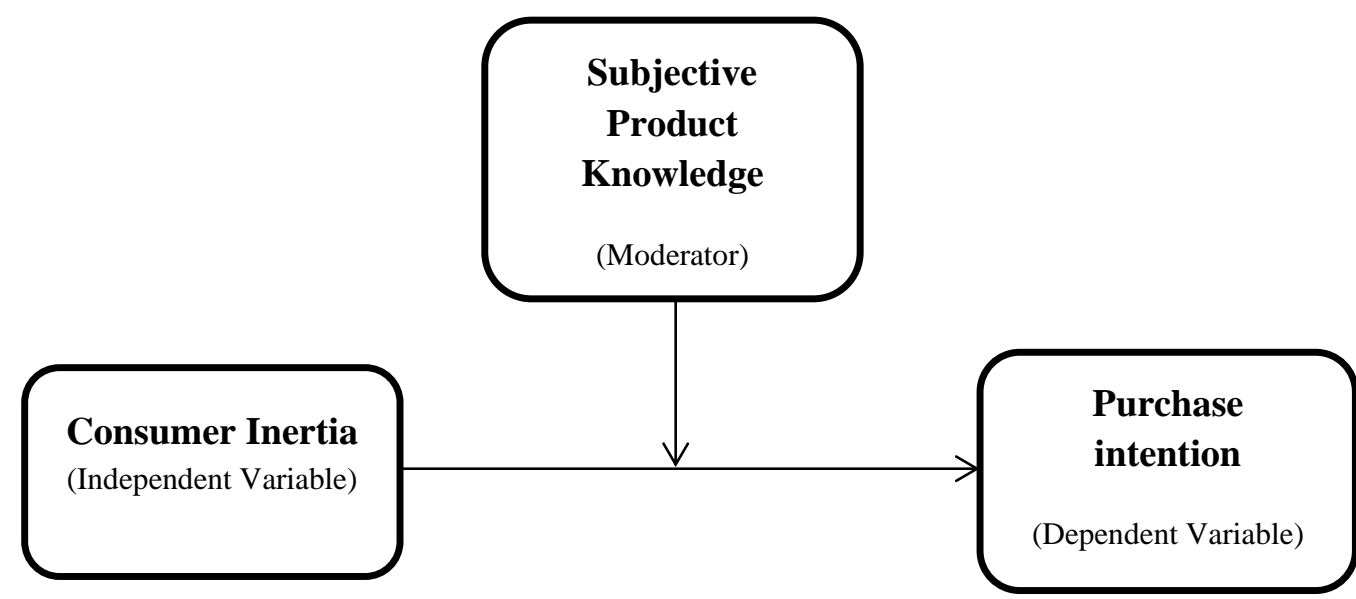

Figure 2.

$\mathrm{H}_{1}=$ Consumer Inertia positively influences the Purchase Intention.

$\mathrm{H}_{2}=$ Subjective Product knowledge positively moderates the relationship between consumer inertia and purchase intention. 
This research was quantitative in nature. Questionnaire was used as research tool to get the response as it was adopted on the basis of literature [1][10]. Cronbach's alpha value is 0.813 which approved the strong reliability of scale. All the questions were assessed by using 5- point likert scale ranging from 1- strongly disagree to 5- strongly agree. It was a cross sectional study. Convenient sampling technique was used in order to get the surveys. Data was collected from 400 people including students of different universities and employees of public and private sectors who had smartphones. For the sake of statistical analysis SPSS was used. Hierarchical regression was applied to test the hypotheses.

\section{Results and Discussion}

This research was carried out to observe the moderating effect of subjective product knowledge between the relationship of consumer inertia and purchase intention. In table 1 descriptive and correlation were calculated.

Table 1. Descriptive and Correlation Analysis

\begin{tabular}{|l|l|l|l|l|l|}
\hline Variables & Mean & St.deviation & 1 & 2 & 3 \\
\hline 1.Inertia & 3.4658 & .80858 & - & & \\
\hline 2.Purchase Intention & 3.8204 & .48054 & $.353^{*}$ & - & \\
\hline $\begin{array}{l}\text { 3.Subjective Product } \\
\text { knowledge }\end{array}$ & 3.3684 & .51830 & $.203^{*}$ & $.534^{*}$ & - \\
\hline
\end{tabular}

("Correlation is significant at 0.01 level)

Data did not contain any missing value. Values of mean showed respondents' inclination towards agreement. Inertia was moderately correlated with purchase intention and weakly correlated with subjective product knowledge whereas; purchase intention and subjective product knowledge were strongly correlated with each other [13].

Table 2. Regression Analysis

\begin{tabular}{|c|c|c|c|c|c|c|}
\hline Model & $\mathrm{F}$ value & $\mathrm{R}^{2}$ & $\mathrm{R}^{2}$ change & Sig & Tolerance & VIF \\
\hline $\begin{array}{c}\text { 1. (Without } \\
\text { Moderation) }\end{array}$ & 56.620 & .125 & .124 & .000 & 1.000 & 1.000 \\
\hline 2.(With Moderation) & 105.680 & .347 & .223 & .000 & .949 & 1.043 \\
\hline
\end{tabular}

Hierarchical regression analysis was applied to check the hypotheses. All the assumptions of regression were met by the data. For multicolinearity the values of variance inflation factor (VIF) and tolerance were checked. The value of variance inflation factor (VIF) was $<10$ and the value of tolerance was $>0.2$ which assured that there was no multicolnearity among the variables which were under studied [1]. Data was normally distributed on the normality plot and histogram. As the data was equally distributed around the scatter plot line so there was no homoscedasticity in the data. The significant values for both models were $<.05$ which showed the significance of the models. It also meant that we failed to reject $\mathrm{H}_{1}$ and $\mathrm{H}_{2}$. In model 1, the value of constant was equal to 3.094 and the value of $\mathrm{B}$ was equal to .210 , it meant that consumer inertia positively affected the purchase intention. The value of $\mathrm{R}^{2}$ is equal to .125 which meant by $12.5 \%$ dependent variable purchase intention was affected by consumer inertia.

In model 2, value of constant $=1.789$ and value of coefficient $b$ (with moderation) was equal to .436. It represented that independent variable and moderator variable combinely affected the dependent variable positively. Results in table 2 showed that consumer inertia 
itself affected the purchase intention $12.5 \%$ but purchase intention was affected $34.7 \%$ by consumer inertia through the moderating role of subjective product knowledge, which confirmed the subjective product knowledge as a good moderator of purchase intention.65.3\% were other factors by which purchase intention was affected. Through moderating role of subjective productive knowledge, it strengthened the relationship between consumer inertia and purchase intention by $22.3 \%$, as value of change in $\mathrm{R}^{2}$ was shown in table 2.

The results of this research suggested that the hypothesis $\mathrm{H}_{1}$ and $\mathrm{H}_{2}$ could be considered as true. Hierarchical Regression analysis's result assured that there was a positive relation between consumer inertia and purchase intention. As consumers re-condescend towards a product, it was definitely affected their purchase intention. Subjective product knowledge was found as a good moderator of purchase intention. It may strengthen the relationship between consumer inertia and purchase intention by a considerable value.

\section{Conclusion}

This study focused the moderating effects of subjective product on purchase intention that may help the managers to understand the reluctant behavior of consumers towards a product which might lead them towards high level of inertia. The results of this research showed that consumer inertia and purchase intention were positively related with each other. Both subjective product knowledge and consumer inertia affected the purchase intention in a positive way and it also found subjective product knowledge as a good moderator of purchase intention. According the results we failed to reject $\mathrm{H}_{1}$ and $\mathrm{H}_{2}$. Subjective product knowledge strengthened the relation between independent and dependent variables. Consumers' high subjective knowledge affected their purchase intention towards a product. On the basis of subjective product knowledge, consumers' purchase intention could be architected. This study may be helpful to understand the effect of consumer inertia on purchase intention keeping subjective product knowledge as moderator.

\section{References}

[1] T. Li Hu, "Effects of inertia and satisfaction in female online shoppers on repeat-purchase intention", Managing Service Quality, vol. 23, no. 3, (2013), pp.168-187.

[2] Oliver, "Whence consumer loyalty?", Journal of Marketing, vol. 63, no. 4, pp. 33-44, (1999).

[3] K. Lee, "Country-of-Origin Effects on Consumer Product Evaluation and Purchase Intention: The Role of Objective Versus Subjective Knowledge", Journal of International Consumer Marketing, vol. 21,no. 2, (2009), pp. 137-151.

[4] S. Olsen, "Certainty, risk and knowledge in the satisfaction-purchase intention relationship in a new product experiment”, Asia Pacific Journal of Marketing and Logistics, vol. 24, no. 1, (2012), pp. 78101.

[5] T. Magistris, "The decision to buy organic food products in Southern Italy", British Food Journal, vol. 110, no. 9, (2008), pp. 929-947.

[6] R. Gulati,'Does familiarity breed trust? The implications of repeated ties for contractual choice in alliance. Academy of Management Journal, vol. 8, no. 1, (1995), pp. 85-112.

[7] Huang, "Are consumers inherently or situationally brand loyal? A set intercorrelation account for conscious brand loyalty and nonconscious inertia", Psychology and Marketing, vol. 16, no. 6, (1999), pp. 523-544.

[8] Oliver, "Customer delight: foundations, findings and managerial insigh", Journal of Retailing, vol. 73, no. 3, (1997), pp. 311-336.

[9] V.A. Zeithaml, "A dynamic process model of service quality: from expectations to behavioral intentions", Journal of Marketing Research, vol. 30, no. 1, (1993), pp. 7-27.

[10] Johnson, M.D., Herrmann, A. and Huber, F. The evolution of loyalty intention. Journal of Marketing. 70(2): 122-32 (2006).

[11] M.D. Johnson, G. Nader and C. Fornell, "Expectations, perceived performance, and customer satisfaction for a complex service: the case of bank loans", Journal of Economic Psychology, pp. 17 no 2, (1996), pp. 163-82. 
[12] J. Aertsens, "Subjective and objective knowledge as determinants of organic vegetables consumption", Food Quality and Preference, vol. 21, no. 2, (2010), pp. 581-588.

[13] Rudell, "Consumer food selection and nutrition information.New York Praeger", vol. 23, no. 3, (1979), pp. 477-497.

[14] P. S. Ellen, "Do we know what we need to know Objective and subjective knowledge effects on proecological behaviors", Journal of Business Research, vol. 30, no. 1, (1994), pp. 43-52.

[15] A. Gracia, "The demand for organic foods in the South of Italy: A discrete choice model", Food Policy, vol. 33, no. 5, (2008), pp. 386-396.

[16] N. Spears, and S. N. Singh, "Measuring attitude toward the brand and purchase intentions", Journal of Current Issues and Research in Advertising, vol. 26, no. 2, (2004), pp. 53-66. 
International Journal of $u-$ and e- Service, Science and Technology Vol.8, No.2 (2015) 